\title{
Wrap-up Comments: To Build a National Commitment
}

Hon. Gerald Merrithew, Minister of State, Forestry. My colleagues and Members of Parliament in the audience, ladies and gentlemen, we have now arrived at what I am sure will be recorded in the future as a very important moment in Canadian history. This Congress is an important stage in the evolution of the forestry community in Canada. It is the first time since 1906 that so large a number of representatives of the different forest sectors have come together to discuss their common interests in forestry. I have the distinct privilege and responsibility of providing a summation on behalf of my colleagues of what has occurred in the fifth and the concluding session of the Congress where we've discussed the elements of a sectorial strategy for Canadian forestry. In the past two days we may have made history. I say we may have made history because it's not clear yet whether this conference will be a watershed in our nation's economic development or will be just another forestry congress, as Jack Munro suggested this morning. Some of you may or may not fully realize exactly how unique it is. I've been in government for about 15 years and can tell you, in all the time l've served in a lot of different portfolios l've never been involved in an event like that which has gone on here in the last two days. You just finished a cross-examination of most of the Forestry Ministers for Canada. That is unique. I've never been in a panel where the public had a chance to go at all of the Ministers in Canada at one table. You've had four federal ministers attend this conference. That's almost unique unless it's a fund raiser.

Once in my home riding, the Prime Minister appeared. The last time a Prime Minister every spoke about forestry was in 1906. The Prime Minister gave a very personal commitment to this community as a critical element of our government's economic program. I'm sure you all noticed that many people gave mixed reviews on the comments he made but l'll tell you, if you didn't see it when he put down his prepared notes and spoke, that is when he showed the commitment to the sector we all serve. Speakers and delegates in this conference represented unions - union leaders here, all of them, the main ones in Canada representing 200000 workers. Executives: I know executives here could have made a lot of money if they weren't here, but they chose to be here. We had the chief executive officers of almost every company in Canada. They represent billions of dollars worth of investment. They shared the stage with academics, the deans of our forestry schools who've been leaders in the development of understanding and of insight. This sort of gathering rarely occurs in other sectors. Don't think it just happens, it doesn't happen. There's a reason why it's happening in this sector. Our nation and its governments, at this table, are searching for directions. We have rediscovered forestry in the last few years, not just as an economic activity but as an inescapable part of Canadian life. But because it's ubiquitous every Canadian has a stake in its future. The beliefs and the interests of millions of people collide, absolutely collide, in the Canadian forests: industry, labour, environmentalists, sportsmen, bankers, campers, scientists, politicians and our children.

Just seven months ago, this group formed the Canadian Council of Forest Ministers. Can you believe it, there never before was a council of forest ministers in Canada to deal with the issues. We used to belong to another organization: it was a good organization but didn't really pay much attention to us. I was one of them. I tell you there's a new group now and they're very, very much aware and we're working very, very well and I'm dedicated to be one of them and dedicated to make things work as we deal with the issues that face our sector.
The first thing as I mentioned today is that we've tried to respond and we're going to try to respond to many of the recommendations you people have passed onto us. One of them was that somehow we have to make the Canadian people aware that our Canadian forestry is not a sunset industry. You know, it still is Canada's largest industry, it still makes the largest contribution to the balance of payments in trade, it still is our largest employer, it still is the only industry in the 300-400 communities in Canada. Somehow or another we've got a group of bureaucrats and others, in certain places, who don't seem to attach the kind of importance to forestry that we in this room do, you and me.

The second thing we said we were going to do was to put together forums sponsored by CCFM, and this was only last September. By March, we had already finished the four across Canada, and the publication at the back on the Canadian Forestry Forums is the result of them. At the forums we asked the finest minds in Canada and elsewhere, not representing just foresters, but the whole sector - environmentalists investors, labour. We asked them all to give us their advice, it's there. It culminated in those recommendations you saw on the screen today. I think that's an indication that your Canadian Council of Forest Ministers is out to do things, to make things happen in your sector. Over the entire forum series many ideas and number of common recommendations emerged. This helped serve as research material for our deliberations at this Congress. As a result of these forums, I think many of the participants and Ministers arrived here with a very much more refined view of the issues which we must deal with. I think this added to the quality. Many of you out there were at these forums and many of you have told us how much you appreciated them and I think they added a great deal to the debate that has taken place over the last two days.

When we leave today and return to our homes, we'll study the speeches and the documents presented here and the insights that have been offered by you people. From all that's been said I believe we'll find consensus for the future and I'm prepared to make a commitment today, on behalf of the Canadian Council of Forest Ministers, to the development of an updated national strategy for the future of Canadian forestry. This strategy will draw upon the results of the Congress, the forums and a broad spectrum of issues that we'll be dealing with in consultations with labour, academia, industry and with all of those others who are interested in the same forests that you're interested in.

My colleagues will agree when I say that forestry is becoming a plum assignment in government. We've been securing huge, comparatively, amounts of new money for reforestation. Under the ERDA agreements, everybody says it's not enough and it isn't enough, but forestry got about a third of all of the money that was available to all of the sectors: agriculture, science and technology, mining. I think that's pretty good. We're seen as the critical players in trade and investment discussed in Cabinet. We're getting this extra clout because of you, because of your growing enthusiasm and your growing agressiveness. it used to be that foresters went to meetings and talked to themselves. If we're going to do better than that; you've got to talk to government and you've got to talk to others in the community. Forestry and its spokesmen are claiming their rightful place in the nation's affairs. I sincerely believe the battle for a current, coherent national forestry effort is being won. This morning we head the suggestion that leadership is lacking. I think this is grossly unfair. In those areas where solutions were obvious, we have 
acted decisively. In reforestation, for example, Canada's efforts increased $400 \%$ in one year. However, difficult and longstanding problems defy easy, simplistic or quick solutions. There are no easy quick fixes. We're now grappling with more complex issues and no one person has easy answers to all of them. We don't at this table. We've seen what happens when governments try to impose solutions on this nation. Our approach is different, it's more co-operative and, perhaps, slower; but the decisions we shall have to make will still be affecting Canada when our grandchildren gather for the next forestry congress, maybe 80 years from now. We owe it to them to get it right the first time.

Last night we heard Gil Grosvenor and his impassioned plea for more wilderness. Yesterday Bernd Koken quietly challenged all of us to strive for excellence and to seek productivity gains in the competitive new world marketplace. This morning Jack Munro, in his colourful language, showed some of the anger of workers caught in the sudden onslaught of technological change. Graham Bruce, a real zealot for our sector, reminded us that towns and regions depend on our success for their existence. Many of the mayors are here today from communities that are directly affected by our sector.

I want to leave you with a thought that sustains me and | think it sustains my colleagues. I believe the people in this room are among the most fortunate in this country. Our problems are tought but they're problems worthy of our best efforts. I feel very privileged to be a part of these issues and to make a contribution, one way or the other, large or small, to our nation's future. Offering Canada a sense of direction and leadership in forestry is what this Congress was all about. I want to say that there is no job more important, nor more rewarding, nor more noble, than accepting that challenge. My colieagues and I had lunch today: we do jointly accept the challenge you've thrown at us

Now that the Congress is nearly ended, I would like to take this occasion to thank all the participants, invited speakers, and panelists for their excellent contributions which ensured the success of this historic event. They've given up a lot of time, a lot of money, to make things happen and to make sure your governments collectively understand your will. Things like this don't happen easily, it takes a long time. I've organized a lot of things like this and it took a lot of years, yes years, certainly many, many months, of very difficult and intensive planning to make things work. Even the package of information you received will help all of you deal with policy issues when you go home. I think the kind of minutes and the way things are done here, the way things have been organized, the panelists - how thoughtful, how thoughtprovoking they were, some of them, how humourous - I think all of that was important to all of us. That didn't come easily, it took a lot of their time, personal time and it's time away from things we might rather do. So to Chuck Geale and to the Canadian Forestry Association, on behalf of the Canadian Council of Forest Ministers, I want to say a very big thank you. 